\title{
THE CROSSING OF THE RUBICON AND THE OUTBREAK OF CIVIL WAR IN CICERO, LUCAN, PLUTARCH, AND SUETONIUS
}

\author{
JeFFREy BENEKER
}

$I_{N}$ In January 49 b.c., Caesar defied the Roman senate and led his army south across the Rubicon, out of his province of Gaul and into Italy. In doing so, he ignited a civil war that brought about the destruction of Pompey, his chief political rival, and secured his complete, if temporary, domination of the republican government. Several contemporary authors wrote about the outbreak of the civil war, but the crossing of the Rubicon itself, now a famous symbol of Caesar's irrevocable decision to invade Italy, does not take on special significance in the extant literary tradition until decades later. Caesar's own commentarii record his passage from Ravenna to Ariminum but, perhaps not surprisingly, are silent about his crossing of the provincial boundary (B Civ. 1.8); Asinius Pollio, who was with Caesar at the Rubicon, almost certainly described the crossing in some detail, but his lost account may be glimpsed only through the filter of later writers, which makes it difficult to discover what significance, if any, he attached to the event; ${ }^{1}$ Cicero's writings include a negative response to the start of the war and to Caesar's actions in general, but they make no mention of the river. Early in the next century, however, the history of Velleius Paterculus provides the earliest extant mention of the Rubicon, marking the point in the surviving literature where the crossing itself begins to be synonymous with the outbreak of civil war, but Velleius includes no details of the event and does not ascribe to it any further significance $(2.49 .4) .^{2}$

It is only in the literature of the Neronian period and later that we find fully developed "Rubicon narratives." As a result, our modern view of the crossing depends almost entirely upon three relatively late passages: an episode in Lucan's epic poem (1.183-235) and the full but differing accounts in the biographies of Caesar by Plutarch (Caes. 32) and Suetonius (Jul. 31-32). By this time, more than a century after the event, the Rubicon has taken on great interpretive meaning, looming large as the thin line between war and peace, between personal ambition and political consensus, and between the old and the new Roman state. Reflection on the history of the first century B.c. from the vantage point of the established principate might have allowed the crossing of the Rubicon to emerge as a pivotal moment in the history of the demise of the republic.

\footnotetext{
${ }^{1}$ Pollio's account of the crossing was the likely source for the later versions of Plutarch, Suetonius, and Appian; see Pelling 1979: 84-85 and Morgan 2000: 55-60.

${ }^{2}$ Livy's account of this period has been lost, and the extant summary for Book 109, which included Caesar's invasion of Italy, does not mention the Rubicon. Florus begins the war at Ariminum (2.13)
}

PHOENIX, VOL. 65 (2011) 1-2. 
Moreover, these imperial narratives, although different in many ways, all share at least one common element, Caesar's hesitation at the river's edge. His deliberation on the brink of war suggests the influence of rhetorical suasoriae. ${ }^{3}$ An established rhetorical tradition, now lost to us, may have inspired authors of poetry and biography to create literary versions of Caesar's deliberation. ${ }^{4}$ These three imperial narratives, however, represent the acme of ancient literary elaboration regarding the Rubicon. Later historians of the civil war put much less or no emphasis on the event: Appian's account ( $B$ Civ. 2.35) is briefer than Plutarch's but very similar in its details, probably reflecting a less elaborate reshaping of Pollio, their common source; and Cassius Dio records the start of the war without mentioning the Rubicon (41.4). ${ }^{5}$

In this article, I bring together some of Cicero's writings about the outbreak of civil war and the Rubicon narratives of Lucan, Plutarch, and Suetonius. Cicero does not mention the Rubicon or comment specifically on Caesar's transgression of the provincial boundary, but there is a cross-reference from Suetonius to Cicero that invites a comparative reading of these two authors. Such a reading, I believe, encourages us to flesh out the angry yet principled response of Cicero, a response to which Suetonius directly alludes but the full implications of which he ignores almost completely. Cicero's response to Caesar's invasion also constitutes an interesting precedent, if not a direct literary antecedent, for the arguments of Lucan's personified Patria, who appears before Caesar at the Rubicon and attempts to halt his advance. Furthermore, comparative readings of the three Rubicon narratives show that none of the authors simply retells the story of Caesar's crossing. On the contrary, each views the crossing teleologically, setting the scene within a broader context that takes into account the present and the future of the Roman state. With the reader's knowledge of the subsequent civil war and dictatorship as a backdrop, these three authors make Caesar pause at the river's edge to ponder the significance of his actions. As he hesitates, they raise questions about justice, patriotism, ambition, and fortune, and they invite the reader also to think carefully about the larger implications of this now momentous event.

I first follow Suetonius' reference back to Cicero, in order to explore how Cicero reacted to the outbreak of civil war and how Suetonius adapted this

${ }^{3}$ Although we have titles for several declamations about events in Caesar's career, none of them is about the Rubicon; see Kohl 1915: nos. 408-413. There are, however, titles for Roman declamations about Caesar in similar situations and for Greek declamations about Alexander deciding

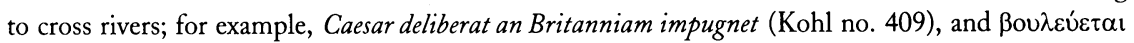

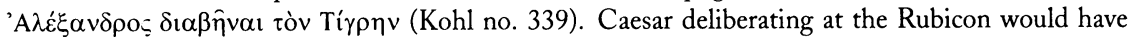
been a natural and even a likely theme, and perhaps it was in vogue not long after the event. On the use of Caesar's career in Roman declamation, see Bonner 1949: 9.

${ }^{4}$ But see Wiseman (1996), who argues for a tragic source behind Suetonius' Rubicon scene.

${ }^{5}$ Cf. Gelzer 1968: 193, n. 3. Excluding larger historical works, modern reconstructions of the crossing include Frank 1907, Dubourdieu 1951, Hohl 1952, and Tucker 1988. For an overview of the ancient sources, see Rondholz 2009. 
reaction for his biography. Next, I compare Suetonius' Rubicon narrative to that of Plutarch, to examine why these two biographers chose to emphasize quite different themes in their handling of the same event. Finally, I turn to Lucan and compare his poetical version of the crossing both to the writings of Cicero and to the other two imperial narratives.

\section{SUETONIUS AND CICERO}

Suetonius prefaces his Rubicon narrative with a chapter devoted to competing explanations of Caesar's decision to leave Gaul and make war against his political opponents. In reporting Caesar's pretext, the Senate's mistreatment of the tribunes of the plebs who exercised their veto on his behalf (30.1), Suetonius reflects the account that appears in Caesar's own commentarii (B Civ. 1.5), but he includes the opinions of other contemporary figures as well, even naming two contemporary sources. Pompey, he writes, claimed that Caesar could not make good on his promises to the people and so hoped to create confusion by starting a war, thereby avoiding his commitments; others, influenced by Cato's threats, thought that Caesar was clinging to his command in order to escape prosecution for crimes committed during his consulship (30.2-4). Suetonius supports this second explanation with an anecdote from Pollio, who reports that after the battle of Pharsalus, Caesar exclaimed that the war was provoked by his enemies' threat to prosecute him if he returned to private life. Suetonius then adds a final possible motive, the opinion that Caesar was provoked into war not by a specific threat but by a general desire to retain power, and in this instance he quotes Cicero in support:

quidam putant captum imperii consuetudine pensitatisque suis et inimicorum viribus usum occasione rapiendae dominationis, quam aetate prima concupisset. quod existimasse videbatur et Cicero scribens de Officiis tertio libro semper Caesarem in ore habuisse Euripidis versus, quos sic ipse convertit:

nam si violandum est ius, regnandi gratia violandum est: aliis rebus pietatem colas.

Some people think that he was captivated by power after holding it for so long, and that once he had weighed his own strength against that of his enemies, he used the occasion to seize control of the state, a thing that he had desired from his very youth. Even Cicero appears to have supposed this, since he wrote in the third book of his De officiis that Caesar always had on his lips some verses of Euripides, which Cicero translates as follows:

If ius must be violated, for the sake of ruling it must be violated; in other matters you should cultivate piety (30.5).

Following this quotation from Cicero, Suetonius moves on to his narration of the crossing itself. But by including this particular passage he has, either deliberately or fortuitously, opened a window into a very rich and bitter interpreta- 
tion of Caesar's decision to engage in civil war. The verses quoted here actually belong to a fairly substantial commentary on Caesar's actions. Cicero has taken them from Euripides' Phoenissae and, according to Suetonius, used them to demonstrate Caesar's long-held desire for power that eventually led to his

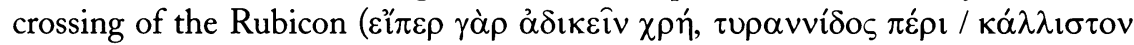

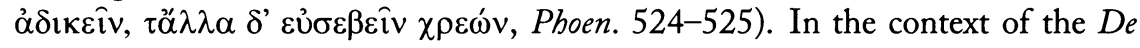
officiis, however, this quotation is not narrowly tied to the crossing. Writing after the Ides of March, Cicero quotes Euripides to make the more general point that both Caesar and Pompey had sought their own advantage at the expense of their country. Cicero, that is to say, was not simply illustrating Caesar's ambition; he was condemning it. A closer look at the larger context of the De officiis reveals that Suetonius changed the tone and thereby blunted the impact of Cicero's remarks when he transferred them to his biography. The full passage from Cicero is as follows:

quid? qui omnia recta et honesta neglegunt, dum modo potentiam consequantur, nonne idem faciunt quod is qui etiam socerum babere voluit eum cuius ipse audacia potens esset. utile ei videbatur plurimum posse alterius invidia; id quam iniustum in patriam et quam turpe esset, non videbat. ipse autem socer in ore semper Graecos versus de Phoenissis habebat, quos dicam ut potero, incondite fortasse, sed tamen, ut res possit intellegi:

nam si violandum est ius, regnandi gratia

violandum est; aliis rebus pietatem colas.

capitalis Eteocles vel potius Euripides, qui id unum quod omnium sceleratissimum fuerit exceperit.

And what about those who disregard everything that is right and honorable, so long as they may pursue power? Are they not doing the same thing as [Pompey] who wished even to make [Caesar] his father-in-law, so that he himself might become powerful through the other man's boldness? It seemed to him most advantageous to be powerful by means of the hatred provoked by the other man. He did not notice how unjust to his country and how repulsive this was. Moreover, the father-in-law himself always had on his lips some Greek verses from the Phoenissae, which I will repeat here as best I can, inelegantly perhaps, but nonetheless, so that my point may be understood:

If ius must be violated, for the sake of ruling

it must be violated; in other matters you should cultivate piety.

Eteocles, or rather Euripides, was guilty of a capital crime, since he exempted the one thing that is most criminal of all (3.82).

Although Cicero names only Eteocles and Euripides, he is by implication sanctioning Caesar's assassination as an appropriate response to his usurpation of power. ${ }^{6}$ The word ius may have a wide range of meanings, but in this context,

${ }^{6}$ I follow Winterbottom (1994) in retaining Eteocles vel potius Euripides in the final sentence. Editors have often deleted this phrase so that Caesar himself becomes the subject, removing the subtlety from Cicero's charge. Dyck (1996: 601-604) notes that Unger retained the phrase but 


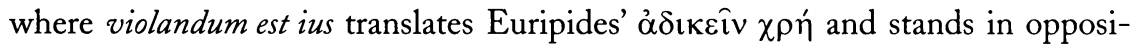
tion to pietatem colas, Caesar's alleged willingness to violate ius implies that he was ready not merely to break laws or ignore decisions of the Senate, but to violate the principle upon which those laws and decisions were based, theoretically at any rate. ${ }^{7}$ Elsewhere in the De officiis, Cicero has cast Caesar's dictatorship in similar terms, calling his purpose impious (causa impia) and his victory more foul (victoria foedior) than Sulla's. To make his case, Cicero argues that Sulla's purpose was honorable (causa honesta) but his conduct after victory was not; Caesar's conduct, on the other hand, since he confiscated entire provinces as well as the property of individuals, was even worse (2.27). Similarly, Cicero asserts that the killing of a tyrant is not morally wrong, because "it does not seem to be wrong to the Roman people" (3.19), a not-so-subtle reference to Caesar's recent fate. ${ }^{8}$ Cicero's attack on Caesar is strongly worded, but he seeks rhetorical safety in ideology and in numbers. By speaking in moral terms and by framing Caesar's aggression as an assault upon ius (and perhaps upon other abstract ideas as well: cf. impia, foedus, turpe), rather than an affront against particular persons, he argues on behalf of his patria. Along these lines, Pompey's accumulation of power also came at the expense of his country and was therefore unjust (iniustum in patriam), and both men are classed among those who disregard everything that is right and honorable (omnia recta et honesta neglegunt). Therefore, Cicero's conflation of Caesar with Eteocles, the lover of tyranny, was a pointed attack on an individual for the violation of a public right. ${ }^{9}$

Defense of the patria was in general a very powerful rhetorical weapon for Romans who wished to justify their own positions and to incriminate their opponents in times of civil war. Cicero made especially good use of it, frequently invoking the patria in his correspondence just after the outbreak of war in 49, as well as in his later writings. ${ }^{10}$ When Suetonius turned to the De officiis in

suggested that "Caesar" be substituted for "Euripides," an emendation (rejected by Dyck on stylistic grounds) that would make Cicero's target especially obvious.

${ }^{7}$ For a clear statement of the relationship between ius and lex in this sense, cf. Sallust $B C 9.1$ : ius bonumque apud eos non legibus magis quam natura valebat. Applied to this particular context, the comment of Ramsey (2007: 82) is enlightening: "Note that ius ('right,' 'justice') may be enforced by a set of laws or statutes but is never defined by these laws. It exists absolutely and provides an absolute standard according to which the laws themselves may be judged as either good or bad."

${ }^{8} \mathrm{Cf}$. 2.26, where the assassination of tyrants is praised and Caesar the dictator is referred to obliquely as bic noster, cf. also Pelling 2006b: 9, n. 14 and Lintott 2008: 372-373. For an extended discussion of Caesar in the De officiis, see Gelzer 1969: 357-362.

${ }^{9}$ Cicero presents a similar argument in the Second Philippic, written around the same time as the De officiis. Assailing Antony's role in the civil war, he repeats his condemnation of Caesar's invasion of Italy on the same patriotic grounds: defense of dignitas is rejected, since he dismisses the pretext that Caesar was provoked into war by the Senate, and ius and patria again form the basis of his attack. Cicero, in fact, rejects all of Caesar's excuses (omitto quam haec falsa, quam levia) by asserting the primacy of the state: there is no just cause that permits an armed attack against one's patria (praesertim cum omnino nulla causa iusta cuiquam esse possit contra patriam arma capiendi, 2.53).

${ }^{10}$ See Jal 1963: 88-90 for general discussion and a list of citations in Cicero's works. 
order to characterize Caesar's ambition, he must have been aware that Cicero's quotation of Euripides would have had political and even partisan overtones. Indeed, as he attempts to explain the motivation behind the crossing of the Rubicon, Suetonius includes the quotation in a list of charges that were made by Caesar's political enemies. But the De officiis as a whole, though highly rhetorical, is aimed primarily at shaping the mores of Cicero's son and, generally, the young men of Rome. In service of that aim, the work contains a strong political message that seeks to promote behavior that is profitable to all citizens, not just individuals, and urges the young Roman reader to identify his own interests with those of the state. ${ }^{11}$ The political lesson of the treatise, according to Andrew Dyck, is "largely subsumed in the rhetorical question" of whether something that is unprofitable for the republic can be profitable to an individual citizen (potest autem quod inutile reipublicae sit, id cuiquam civi utile esse?, 3.101). ${ }^{12}$ In Cicero's De officiis, the ethical and the political cases against Caesar were one and the same. ${ }^{13}$

The case that Cicero makes against Caesar in the De officiis is not, however, an ad hoc argument. Rather, it is the expression of long-held beliefs, grounded both in his political philosophy and in his real experience of the civil war. He was never deaf to Caesar's justifications, especially where they concerned the defense of dignitas, but he was outraged at his willingness to set his own honor above that of the republic. ${ }^{14}$ The theoretical basis for Cicero's outrage came directly from his belief about how the individual citizen related to the Roman state. In his chapter on "The Idea of the State," Neal Wood underscores the importance of the shared or public interest in Cicero's conception of the republic, as expressed even before the war in the De republica:

${ }^{11}$ See the summary of Cicero's political message at Dyck 1996: 31-35.

${ }^{12}$ Dyck 1996: 35. For Cicero, patria and res publica refer to the same institution, though as Wood (1988: 139) explains, "patria tends to be more emotive, res publica more practical in meaning, designating actual political institutions and arrangements aimed at justice and the common interest."

${ }^{13}$ Although its rhetoric is more factional, the Second Philippic also employs this basic notion of patria over civis, and throughout it Cicero attacks both Caesar and Antony for advancing their own interests at the expense of the state; cf. Phil. 2.64: Caesar Alexandria se recepit felix, ut sibi quidem videbatur; mea autem sententia, qui rei publicae sit infelix, felix esse nemo potest. (I have followed here the text of Ramsey [2003], but other readings, which have hostis for infelix, make the same point.)

${ }^{14}$ For dignitas as justification for war, see Caesar's exhortation of his troops at Ravenna (bortatur ... ut eius existimationem dignitatemque ab inimicis defendant, $B$ Civ. 1.7) and his longer speech at $B$ Civ. 1.9. Raaflaub (1974: 151, n. 198) identifies the violation of the public good as the point where Cicero's tolerance of Caesar's arguments changed to stiff resistance: "Insofern hier Caesars dignitasAnspruch das Komplement zur Abwehr von persönlichem Unrecht ... bildet, also gewissermaßen defensiven Charakter hat, wird er von Cicero anerkannt und unterstützt. Wenn er jedoch auf Kosten des Gemeinwohls verabsolutiert wird, allein auf politischen Machtgewinn abgestimmt ist und sogar zur Rechtfertigung eines Bürgerkrieges dient, lehnt ihn Cicero grundsätzlich ab (so in Att 7, 11, 1)." Brunt (1986: 15-16) notes that Cicero was concerned about his own dignitas in the period following the Rubicon; see also Long 1995: 216-218 on the acceptability of acquiring glory in exchange for service to the state. I will examine Att. 7.11 in more detail below, 80-81. 
Cicero begins his definition by identifying state or res publica with res populi, an equation he subsequently emphasizes. He then asserts that a people (populus) are not any random collection of human beings, but "a union of a large number of men in agreement in respect to what is right and just and associated in the common interest." [Rep. 1.39: sed coetus multitudinis iuris consensus et utilitatis communione sociatus.] By defining populus in this way, he also in effect defines the state or res publica, since he identifies res publica with respopuli. The state, then, is the property of a people joined together by justice or right (ius) and common interest (utilitas). ${ }^{15}$

When Caesar turned to civil war in order to secure his own interests, therefore, Cicero saw him as violating his idea of the state in a fundamental way. Moreover, his characterization of Caesar in the De officiis as tyrannical and selfinterested, while rhetorically necessary for his argument, also stems directly from his initial reaction to Caesar's invasion of Italy. In fact, in a letter written to Atticus in January of 49, within days of the crossing of the Rubicon, Cicero also quoted from the Phoenissae in order to mock Caesar's rationale for making war (Att. 7.11). ${ }^{16}$ Eteocles, it turns out, was a useful model for Cicero's opposition to Caesar from the very start of the civil war, making Suetonius' quotation from the De officiis even more closely tied to the Rubicon than it appears to be at first glance. A brief summary of the letter shows that Cicero's anger at the invasion is indeed firmly rooted in his republican ideals. He opens with themes that he will revisit when he attacks Caesar's "tyranny" again after the Ides of March in the De officiis and Second Philippic: he dismisses Caesar's primary justification for war, the protection of his dignitas, by charging him with a lack of honestas in his actions. There can be no dignitas to protect if bonestas is absent. He further complains that Caesar has never seen "even a shadow of the good ( $\kappa \alpha \lambda \mathrm{o})$ )" and continues by setting out precisely why Caesar's actions lack bonestas: he charges that it is not honestum "to retain an army without consent of the state (nullo publico consilio), to capture the cities of one's fellow citizens so that an attack on one's country (aditus ad patriam) may be easier, to undertake the cancellation of debts, the return of exiles, and hundreds of other misdeeds, 'so

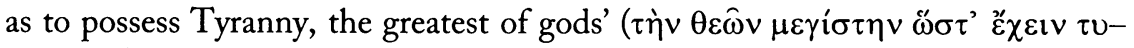
$\rho \alpha v v i \delta \alpha)$." With this closing quotation, Cicero first adduces Euripides' Phoenissae to express his anger at Caesar's commencement of civil war-he is, in fact, quoting from the very same speech of Eteocles that he quotes from in the $D e$ officiis. ${ }^{17}$ Cicero could almost certainly assume that Atticus would recognize the source of the quotation and be familiar with its context, since it is likely that

\footnotetext{
${ }^{15}$ Wood 1988: 126.

${ }^{16}$ Gelzer (1968: 197, n. 2) connects the two references and suggests that the parallel may in fact have originated with Caesar, as Cicero claims in the De officiis. According to Shackleton Bailey (1968: 297-298), the date of Att. 7.11 was most likely January 21, 49 B.c. Caesar probably crossed the Rubicon on January 10, but perhaps as late as January 14; see Gelzer 1968: 192, n. 3.

${ }^{17}$ Phoen. 506. The full speech is at 499-525, with the two verses quoted in De officiis coming at the end.
} 
they both had studied the Phoenissae in their youth and knew it as a work that explored the themes of patriotism and sacrifice for one's country. ${ }^{18}$. If Atticus did indeed recall the context of Eteocles' remark, he received from Cicero a damning comment on Caesar's invasion of Italy: "For I will speak, mother, and hold nothing back: / I would go to where the stars or sun rise / and below the earth, if I were able to do these things, so as to possess Tyranny, the greatest of gods" (Phoen. 503-506). As Cicero presents the situation, Caesar's lack of honestas manifested itself in a willingness to attack the state (aditus ad patriam) and to subordinate the public's interests to his own (nullo publico consilio). Citing other correspondence from this period, P. A. Brunt shows that Atticus was encouraging Cicero not to surrender his notion of the ideal statesman in the midst of the constitutional crisis: "Hence Atticus was right to adjure him to recall his own deeds, words and writings (Att. 8.2.2) and to remind him that in [the De republica] he had identified the bonum with the bonestum (as he was to do in De officiis), and should therefore subordinate everything to his country's good (Att. 10.4.4)." ${ }^{19}$ In Att. 7.11, therefore, Cicero is holding to his ideals in an especially colorful way by complaining that Caesar has never glimpsed $\tau$ ò $\kappa \alpha \lambda$ óv and by characterizing his desire for tyranny with a literary allusion to the Euripidean Eteocles. ${ }^{20}$

For Cicero, then, Caesar's conscious imitation of Eteocles may indeed demonstrate a lifelong ambition, as Suetonius suggests, but it means much more. ${ }^{21}$ Primarily it indicates a subversion of republican ideals, something that Cicero, even in highly rhetorical works, truly considered offensive. Since Cicero's conception of the republic depended so heavily upon consensus about the public interest, we

${ }^{18}$ Cribiore (2001) examines school papyri from Greco-Roman Egypt and concludes that the Phoenissae was studied at all stages of Greek education. She argues that this play was especially popular because it explored devotion to one's country, among other themes. Rawson (1970: 111-112) argues that the theme of patriotic duty was alive for Euripides' first audience as well. Cicero and Atticus might have first encountered the Phoenissae while studying the Greek dramatic poets as adolescents in Rome; cf. Rawson 1975: 7. They could also have had further contact with the play later in Athens. Their shared educational experience would have made Cicero's reference recognizable to Atticus, both as a quotation and as a pointer to the play's larger themes; cf. Clarke 1968: 19 on Cicero's quotations of Homer, and below, 82, on the parallels between the Phoenissae and Cicero's own political ideas.

${ }^{19}$ Brunt 1986: 14 (emphasis original). Att. 8.2 was written on February 17 and Att. 10.4 on April 14; see Shackleton Bailey 1968: 50-51, 224-225. The unwillingness of the principals to subordinate their own interest to those of the state is neatly captured in Caesar's famous claim to have been harmed by Pompey's refusal to tolerate an equal (quod neminem dignitate secum exaequari volebat totum se ab eius amicitia averterat, B Civ. 1.4.4) and in Lucan's version of the same idea, which assigns the guilt more evenly (nec quemquam iam ferre potest Caesarve priorem / Pompeiusve parem, $1.125-126)$.

${ }^{20}$ In the same letter, Cicero wonders if he is hearing news about an invasion by Hannibal or by Caesar, declining to name Caesar but underscoring his violation of the public's trust by calling him imperator populi Romani (7.11.1).

${ }^{21}$ That Caesar was aiming for sole rule from his early career is not generally accepted: see Yavetz 1971: $184-185$. 
can easily see how he would represent Caesar's methods (nullo publico consilio), actions (aditus ad patriam), and motto (ius violandum est) as tyrannical, even when Caesar has only just crossed the Rubicon. Moreover, Euripides' play, with its theme of conflict between brothers and emphasis on sacrifice for one's country, provided the ideal vehicle for expressing his indignation. In the Phoenissae, the verses quoted by Cicero are spoken by Eteocles to his mother, Jocasta, as he rejects her attempt to reconcile him to his brother, Polyneices. Polyneices expects to share the Theban throne, but Eteocles is unwilling to relinquish power. Now the army of Polyneices is arrayed outside the walls of Thebes, and Jocasta has come forward to avert this war between brothers. Eteocles rejects her appeal in a speech that openly proclaims his devotion to the goddess Tyrannis, including the verse quoted in the letter to Atticus, and culminates with the boast about the overthrow of justice, as quoted in the De officiis and by Suetonius. Cicero's emphasis on the family relationship between Caesar and Pompey invites a comparison to Eteocles and Polyneices, brothers willing to attack each other and their own country for the sake of power. And if we consider Jocasta's response, we discover in Cicero's brief reference an even more thorough condemnation of Caesar. Jocasta counters Eteocles' oft-quoted boast with principles well suited to Cicero's political outlook. In a lengthy speech (528-586), she rebuts Eteocles' notion of "the finest thing" by proposing something better, equality. She argues that Eteocles ought to respect the deity Isotes, so that neither brother dominates

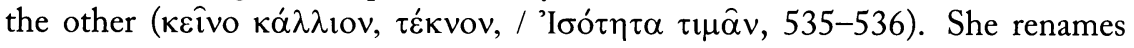
Eteocles' patron goddess Pbilotimia, and she warns him twice about the injustice

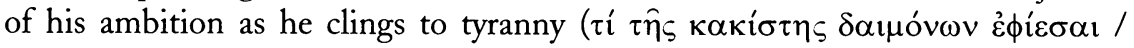

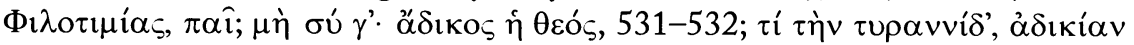

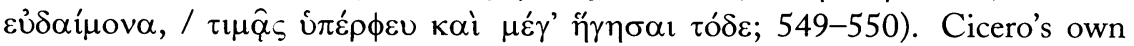
notions of ius and the common interest are defended admirably, but to no avail, in Jocasta's speech. His complaints in the letter to Atticus and in the De officiis, to be sure, are strengthened if his readers recall this whole scene, and all the more so if they reflect further on the mythical conflict's fatal conclusion. ${ }^{22}$

Before returning to Suetonius, to see what sort of resonance this weighty allusion to Eteocles has in his text, I would like first to comment briefly on the general relationship between Cicero and Caesar during and after the civil war. Cicero was certainly angered by the outbreak of war, but his relationship to Caesar, especially following Pharsalus, was complicated. Any assessment of his writings must also take into account the more positive characterizations

\footnotetext{
${ }^{22}$ Cribiore (2001: 248) argues that the character Menoeceus was also appealing to those who admired the Phoenissae for its theme of patriotism. This character, invented by Euripides, emerges as the only citizen who is willing to sacrifice himself for his city rather than vice versa: "The contrast between the selfless idealism of Menoeceus and the callousness or self-interest of the other three main male characters was striking." In calling the Phoenissae to his readers' minds, did Cicero wish to be seen as a Roman Menoeceus, willing to sacrifice his life for the good of the state? Cf. Phil. $2.118-119$
} 
found in his other works. ${ }^{23}$ But even when Cicero is complimentary, as in the Pro Marcello, a speech praising Caesar for his pardoning of the Pompeian Marcus Marcellus, his political ideals have not been set aside. Indeed, we cannot consider this speech without mentioning what was perhaps the real source of Cicero's gratitude: "a glimpse of the respublica coming alive again" (Fam. 4.4.3). The speech itself is somewhat vague in its depiction of Caesar's actions in this regard, but "after nearly four years of arbitrary government, it is the idea of a return to constitutional forms that dominates." ${ }^{24}$ Cicero, however, would be disappointed: "within three months or so between the pardon of Marcellus and Caesar's departure for Spain (where Pompey's sons had rekindled the war) it became plain that nothing was to be hoped in this direction." 25 A fair characterization of Cicero's post-Rubicon attitude toward Caesar, therefore, has to balance his friendly relations and praise for the dictator with the fact that he never relinquished his desire to see the republican constitution restored and, as D. R. Shackleton Bailey has said, never "in his heart" retracted the anger that he expressed in January of $49 .{ }^{26}$ That is to say, his characterization of Caesar as Eteocles in the De officiis, even after the Ides of March, still had teeth.

In Suetonius' narrative, however, the quotation from Cicero is allowed very little bite. It seems only to support the opinion that Caesar took advantage of the relative weakness of his opponents in order to satisfy a long-held desire for absolute power. While Cicero used Eteocles to raise questions about Caesar's disregard for basic republican concepts like patria and ius, Suetonius has actually shaped his narrative in order to keep such questions at bay. To be sure, his narrative speaks to the outbreak of civil war and, by extension, to the fall of the republic, but he gives the reader little opportunity to evaluate Caesar's role in either event. Suetonius is not generally protective of Caesar or blind to his faults. He could be especially critical of his political conduct, as when he begins to narrate Caesar's assassination:

praegravant tamen cetera facta dictaque eius, ut et abusus dominatione et iure caesus existimetur.

Nonetheless, his other words and deeds were burdensome, so that he was considered to have abused his power and to have been killed justly (Jul. 76.1).

\footnotetext{
${ }^{23}$ Shackleton Bailey (1971: 197-199) cites positive views of Rome under Caesar in Cicero's correspondence following his return to Italy in 47 B.c. Other positive characterizations are to be found in the Caesarian speeches (Pro Marcello, Pro Ligario, and Pro rege Deiotaro) and in the assessment of Caesar's rhetorical style in Brutus (251-262). Stockton (1971: 264-275) describes generally good personal relations between Cicero and Caesar during this same period.

${ }^{24}$ Stockton 1971: 274; see further Lintott 2008: 313-322. Dyer (1990) argues that the Pro Marcello is really a veiled attack on Caesar's despotism. For the rhetorical and political complexity of this and the other Caesarian speeches, see Gotoff 1993: xxix-xl.

${ }^{25}$ Shackleton Bailey 1971: 199.

${ }^{26}$ Shackleton Bailey 1971: 146.
} 
This criticism refers to Caesar's abuse of power rather than to his acquisition of it. That is, Suetonius sees justice in the assassination of Caesar for arrogant deeds performed after he gained control of the government. ${ }^{27}$ But Suetonius does not criticize, here or elsewhere, the seizure of power itself. Therefore, even as he quotes Cicero in setting his Rubicon scene, he ignores the real meaning of Cicero's argument, showing, as usual, little interest in larger political questions. ${ }^{28}$

Not only does Suetonius' narrative avoid direct comment on how the republic fell; it appears even to encourage acceptance of its demise. Suetonius ignores some of the most vehement criticism of Caesar's actions, which lay just below the surface of his quotation of Cicero, and presents instead a subtly crafted statement about the positive role of fortune. In fact, in Suetonius' account, the civil war was brought about by both human and divine action. Caesar deliberates at the river's edge, but ultimately the decision to cross is made by a higher power. This element of the story creates the impression that his invasion of Italy and subsequent dictatorship could hardly have been motivated by self-interest alone.

After recounting the possible political reasons for Caesar's crossing (30), Suetonius moves on to the event itself. Caesar's tribunes flee Rome after their veto has been denied; then Caesar quickly arranges his exit from Ravenna under cover of darkness, moving along narrow pathways and even losing his way in order to travel by the occultissimum iter (31.1-2), until he reaches the border of Italy:

consecutusque cohortis ad Rubiconem fumen, qui provinciae eius finis erat, paulum constitit, ac reputans quantum moliretur, conversus ad proximos: "etiam nunc," inquit, "regredi possumus; quod si ponticulum transierimus, omnia armis agenda erunt."

He came upon his cohorts at the river Rubicon, which was the boundary of his province, and stopped briefly. As he considered the magnitude of his undertaking, he turned to his companions and said, "Even now we can turn back, but once we have crossed this little bridge, everything will have to be settled by fighting" (31.2).

Despite the serious questions that might have been raised by the quotation of Cicero and Euripides just a few lines above, Suetonius' Caesar does not dwell long, if at all, on whether or not his crossing is right. His remark that "everything will have to be settled by fighting" is at best a nod toward the fact that his action is an attack upon the state and that the ensuing conflict, unlike his many battles in Gaul, will be a civil war. Caesar's neatly stated, binary problem (should I stay or should I go?) might have invited reflection on these larger issues, as it would have done in suasoriae based on the crossing and as it did in Lucan, as we shall see. But before Caesar can consider the reasons for not crossing-and so before Suetonius has to enumerate them in his text-something forces his hand:

\footnotetext{
${ }^{27}$ Suetonius begins this statement with tamen because he has just dedicated the previous chapter to examples of Caesar's leniency. Despite this, Caesar's abuse of power justified his murder. Bradley (1991: 3703) calls Jul. 76.1 "a sentence that should leave no doubt of Suetonius' view of Caesar's abuses of power and consequently justifiable (though not necessarily condoned) assassination."

${ }^{28}$ See, for example, Cizek 1977: 178; Bradley 1991: 3716; and Wallace-Hadrill 1983: 110-112.
} 
cunctanti ostentum tale factum est. quidam eximia magnitudine et forma in proximo sedens repente apparuit harundine canens; ad quem audiendum cum praeter pastores plurimi etiam ex stationibus milites concurrissent interque eos et aeneatores, rapta ab uno tuba prosilivit ad flumen et ingenti spiritu classicum exorsus pertendit ad alteram ripam. tunc Caesar: "eatur," inquit, "quo deorum ostenta et inimicorum iniquitas vocat. iacta alea est," inquit.

Such a prodigy occurred before him as he hesitated: a figure of extraordinary size and beauty suddenly appeared near by, sitting and playing a flute. When not only a great many of the shepherds came to hear it but even the soldiers ran from their posts, among them the trumpeters, then the figure seized a trumpet from one of them and leapt toward the river, and sounding the call with a great blast, it made for the opposite bank. Then Caesar said, "Let us go where the signs of the gods and the unfairness of our enemies call. The die has been cast" (32).

Suetonius has essentially cut off discussion about the correctness of Caesar's action. He is not endorsing the civil war or Caesar's subsequent domination of the state; rather he is presenting the events as inevitable. Just as he sidestepped Cicero's complaint about the assault on republican ideals, Suetonius here does not seriously consider Caesar's question about the propriety of making war against his political enemies. His narrative effectively makes this issue irrelevant, for both his subject and his reader.

\section{SUETONIUS AND PLUTARCH}

Suetonius has crafted his scene of Caesar's hesitation at the river's edge so as to push the question of justice into the background. We can get a better idea of how Suetonius has shaped his narrative by considering Plutarch's earlier version of this same event. Both authors most likely used Pollio as their direct or indirect source, but their adaptations result in quite different interpretations. ${ }^{29}$ Plutarch, who also recounts Caesar's night-time journey from Ravenna to the Rubicon, prefers a more reflective Caesar:

Then he turned in the direction of Ariminum, and when he arrived at the river that divides Cisalpine Gaul from the rest of Italy, called the Rubicon, a reasoning came upon him as he drew even closer to the awesome deed and was bewildered by the magnitude of what he was daring to do, so he stopped his cart. Having halted the journey, he debated repeatedly within himself, silently taking one decision then the other, and at that time his conclusion changed over and over. And for some time he shared his doubts with those of his friends who were present, including Asinius Pollio, calculating what great evils the crossing would bring to all people and how great a reputation they would leave to future generations. Finally, with a certain spirit, as if casting himself away from his reckoning and toward the future, and uttering that saying which is common to men who

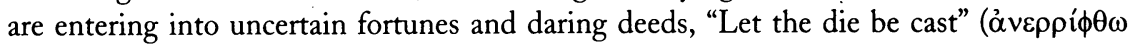
$\kappa u ́(\beta) \varsigma)$, he rushed to cross the river. He completed the rest of his journey at a run, then fell upon Ariminum before dawn and took the city. On the night before his crossing he

\footnotetext{
${ }^{29}$ See above, 74, n. 1.
} 
is said to have seen a strange dream: he appeared to be lying with his own mother-the unspeakable union (32.5-9).

Suetonius and Plutarch both have Caesar dwelling on essentially the same question, whether to cross or to remain in Gaul. But Plutarch emphasizes Caesar's aporia, which is never actually resolved. ${ }^{30}$ Still in the midst of his reckoning, Caesar acts with the aid of impulse rather than by reason alone, and he hands the undecided question to fortune. ${ }^{31} \mathrm{We}$ must notice, too, that only in Plutarch's version is Caesar allowed to doubt his ultimate success. In Suetonius, Caesar is troubled by the civil war in general (omnia armis agenda erunt), but he has already dreamed of intercourse with his mother, which was interpreted for him as a promise of world domination. ${ }^{32}$ In Plutarch, Caesar wonders whether

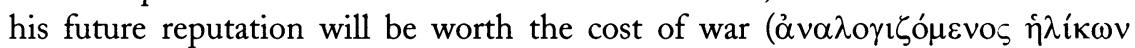

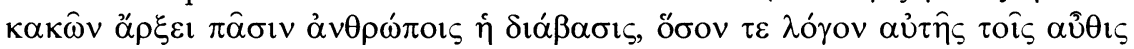
$\alpha \pi \mathrm{\alpha} \lambda \varepsilon i\left(\mathrm{ov}_{\mathrm{o}}\right)$, but the same dream about intercourse serves to underscore the mental anguish caused by this dilemma. Plutarch, unlike Suetonius, reports the dream without the positive interpretation, even drawing attention to its repulsiveness, in order to make the scene at the Rubicon even more troubling for Caesar, and perhaps for the reader as well. ${ }^{33}$ Plutarch's Caesar, when he finally crosses the river, truly does not know the answer to his question. Therefore his expression, "let the die be cast," is entirely appropriate since he is, as Plutarch

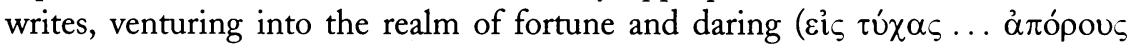

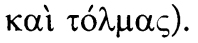

Suetonius' Caesar, however, does not feel the same uncertainty as he crosses the Rubicon. No sooner has he expressed his concern about fighting than his doubt is removed in a vivid and unmistakable way. His reaction to the apparition is famous but not without controversy, as scholars have long noticed that Suetonius' Caesar proclaims that "the die has been cast" (iacta alea est) rather than demanding "let the die be cast" as Plutarch's Caesar does. ${ }^{34}$ Long ago, Erasmus suggested that est be emended to esto, so that Suetonius' text would conform to the Greek tradition in its use of the imperative rather than the

${ }^{30}$ Cf. Buszard 2008.

${ }^{31}$ See Duff 1999: 72-98 for a discussion of the interplay between reason and spirit in the soul of a Plutarchan hero.

${ }^{32} \mathrm{Jul}$. 7.2: etiam confusum eum somnio proximae noctis-nam visus erat per quietem stuprum matri intulisse-coniectores ad amplissimam spem incitaverunt arbitrium terrarum orbis protendi interpretantes, quando mater, quam subiectam sibi vidisset, non alia esset quam terra, quae omnium parens haberetur. In Suetonius, Caesar sees this dream twenty years before the Rubicon, during his quaestorship in Spain; cf. Cass. Dio 37.52.2.

${ }^{33}$ Cf. Duff 1999: 80, n. 29: "Caesar's self-doubt at invading his country erupts in this disturbing dream in which he invades another sort of forbidden territory." See Pelling 1997: 200-201 on the ambiguity of the dream's message. Plutarch, as Pelling and Duff note, even appears to have adapted the timing of this dream in order to suit his purpose.

${ }^{34}$ Plutarch's Caesar makes the same exclamation at Pomp. 60.4, as does Appian's (B Civ. 2.35). 
indicative. ${ }^{35}$ After discussing the origin of the proverb in Menander (fr. 59.4 Koerte) and noting a variant in Aristophanes (fr. 673 Kock), Robert Renehan has supported this emendation:

Strictly speaking the "die was not cast" until after Caesar crossed the Rubicon; iacta alea est is slightly illogical. But this distinction must not and need not be pressed. It is clear from the evidence presented above that Suetonius, who certainly knew the famous story, is here translating the Greek proverb $\alpha \dot{\alpha} \varepsilon \rho \rho i \phi \theta \omega$ кúßos; the Greek has a perfect imperative and Suetonius rendered it by a Latin perfect imperative: iacta alea esto. est of the Mss is nothing but a trivialization of the commonest sort. The rare perfect imperative corrupted to a familiar perfect indicative. ${ }^{36}$

While Renehan's suggestion that the text has been corrupted is entirely sensible, I would like to address the logical dimension of his argument, which Renehan does not stress but which, I believe, casts doubt on the need for emendation. When Suetonius' Caesar utters his famous line at the end of chapter 32, he has, strictly speaking, already crossed the Rubicon: the apparition, "sounding the call with a great blast, made for the opposite bank" and evidently began to lead Caesar's army into Italy. Although Caesar himself is standing on the north bank, thanks to the decisiveness of the apparition acting in his place he has transgressed the boundary of his province and so commenced civil war. His question about whether to commit the dispute to arms has been answered; the die has been cast and the result of the throw is known. Suetonius has Caesar confess as much by making him say: "Let us go where the signs of the gods and the unfairness of our enemies call." This statement is the one that applies to the future, and it appropriately has the imperative, in the form of a jussive subjunctive. In this reading, iacta alea est justifies Caesar's call to arms rather than assigning it to the whim of fortune.

Suetonius' Caesar thus admits that he knows that his action is aligned with the divine will, whereas Plutarch's Caesar is left to wonder how the die will fall and whether he has made the right decision, even as he pushes ahead into civil war. This, I suggest, is the principal point of Plutarch's Rubicon narrative. Throughout his Parallel Lives Plutarch is concerned as much with his hero's moral behavior as with his place in history, and in the Life of Caesar he is primarily demonstrating to his readers the dangers of unrestrained ambition. ${ }^{37}$ Caesar never resolves his doubt and must wait until the end of the war before knowing whether his victory will be worth the cost. Even then, however, Plutarch is ambivalent. After describing the war, the dictatorship, and Caesar's

${ }^{35}$ See Butler et al. 1982: 85.

${ }^{36}$ Renehan 1969: 53-55.

${ }^{37}$ Cf. Wallace-Hadrill 1983: 108: "Plutarch by comparison [with Suetonius] is too concerned with Caesar's ambition as a moral failing to perceive its social context." Pelling (2004: 318) argues that the hesitation at the Rubicon is uncharacteristic of Plutarch's decisive Caesar. The unwillingness to wait for fortune to make up its mind does seem in character, however, and continues a theme from the Life of Alexander, cf. Alex. 26 and Caes. 38. See also Pelling 2002b and Beneker 2002/2003. 
subsequent assassination, he wonders whether Caesar's ambition really produced anything worthwhile: "From the absolute power that he barely acquired after pursuing it at great risk throughout his whole life, Caesar derived nothing but a reputation and a fame that was envied by his fellow citizens" (Caes. 69.1). ${ }^{38}$ Even if the perfect indicative of Suetonius' text is the result of a copyist's error, the "figure of extraordinary size and beauty" which appears at Caesar's moment of crisis changes the equation. There is no doubting that Suetonius' Caesar has staked much less on the roll of the die than Plutarch's Caesar has. ${ }^{39}$

Moreover, the 'providential nudge that Suetonius' Caesar receives serves to reassure the reader as well as the imperator. Dreams and signs are a regular part of Suetonius' characterization of all the Caesars' lives, including the life of Julius: I have already mentioned the dream of world domination (Jul. 7.2); Suetonius also includes the famous comet that confirmed Caesar's divinity ( $\mathrm{Jul}$. 88). I see no reason not to include the apparition at the Rubicon in this same category, in which case it would certainly indicate the propriety of Caesar's crossing and would justify the focus on Caesar as an agent of constitutional change. ${ }^{40}$ By not allowing time for questions about the patria or citizenship, Suetonius' apparition at the Rubicon quietly signals the irrelevance of these ideas and even supplies a supernatural endorsement for Caesar's invasion. This divine approval would be a natural development in the story of Caesar, who became a god very quickly after his assassination. ${ }^{41}$

The apparition, however, does not appear in the versions of Plutarch and Appian, although those authors and Suetonius all knew and used the history of Asinius Pollio, or an intermediate source based on Pollio. Perhaps it had become part of the rhetorical or dramatic tradition. Suetonius may also be responding to Lucan's narrative, since among the extant accounts Lucan supplies the only antecedent. ${ }^{42}$ Rather than push Caesar to cross, however, Lucan's ghost urged him to remain in Gaul. If Suetonius was inspired by Lucan's story, then

\footnotetext{
${ }^{38}$ There is some similarity between Plutarch's assessment of Caesar's career and Jocasta's belittling

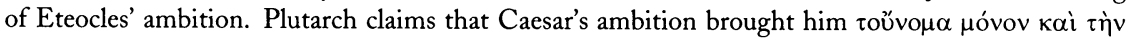
$\dot{\varepsilon} \pi \dot{\phi} \phi \theta o v o v . . . \delta$ ó $\xi \alpha v$, while Jocasta charges that Eteocles' wish to be viewed as a tyrant is an empty

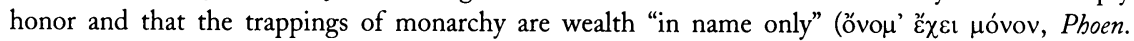
549-554). See also Pelling 2006a: 267.

${ }^{39}$ Plutarch, however, does allow providence to speak more clearly at other moments in Caesar's life; cf. Caes. 63, where he lists the portents that preceded the Ides of March. On Plutarch's general views about the role of the divine will in Roman history, see Swain 1989.

${ }^{40} \mathrm{Cf}$. Wallace-Hadrill 1983: 192: “Behind Suetonius' signs lies the assumption that the course of future events is predestined, and that destiny can be foreseen if one reads the signs aright. It is an attitude to portents radically different from the republican one. It also involves a vital shift in interest from the fortunes of the state to the fortunes of the individuals upon whom the state depended."

${ }^{41}$ On Caesar's divinity, see Weinstock 1971: 364-384.

${ }^{42}$ Lucan (1.526-583) also has a comet appear as Pompey abandons Rome following the invasion, along with various other signs; the elder Pliny (2.92) describes a comet associated generally with the civil war; Appian (2.36) provides a list of portents (but not the apparition at the river) related
} 
his inversion of its message further reinforces the conclusion that for him the republic was meant to fall rather than merely being destroyed by overly ambitious politicians.

\section{LUCAN}

The new role for the apparition is not the only difference between Suetonius' narrative and Lucan's earlier version. Lucan's poem is the first extant text to present the crossing in any detail, but his narrative includes themes that were neglected by the later writers. It engages directly with the notions of patria and ius, which were basic rhetorical and ideological elements in Cicero's arguments against Caesar but which Suetonius would later leave in the background, as we have seen. In Lucan's text, an epic poem rather than a philosophical treatise or an epistle, the characters naturally take center stage, but their words and deeds reveal that Lucan wanted his readers to consider both the larger meaning and the consequences of the crossing.

Lucan begins the scene at the Rubicon by making the Roman Patria, personified in the extraordinary phantom (ingens... imago) of a mourning woman, confront Caesar over the justice of his action just as he approaches the river $(1.185-190){ }^{43}$ She is unmistakable (clara per obscuram ... noctem), and her message is direct:

$$
\begin{aligned}
& \text { "quo tenditis ultra? } \\
& \text { quo fertis mea signa, viri? si iure venitis, } \\
& \text { si cives, buc usque licet." }
\end{aligned}
$$

"Where are you going, beyond here?

Where are you bearing my standards, men? If you come rightfully, if as citizens, you may advance only up to here."

The image of Patria explains to Caesar, in no uncertain terms, that if he is to act rightly and as a citizen should, he must keep his army north of the river. The right conduct of citizens is, in fact, an important theme in Lucan's first book, as established by the poem's opening lines, which promise a story of "wars worse than civil wars" (bella...plus quam civilia) and "ius handed over to crime" (1.1-2). This theme continues even after the war has begun, as Lucan

to Caesar's advance. Suetonius knew, or knew of, Lucan's poem, though in his Life of Lucan he includes no details of the text. However, he appears not to have been opposed in principle to Lucan's form of the apparition: in his Life of Claudius, Suetonius describes a female apparition that stops Drusus from pursuing Germans too far north of the Rhine (Cl. 1.2); cf. Narducci 2002: 198-199.

${ }^{43}$ Walde (2006: 51-52) suggests that Patria could be a dream vision or an apparition. I think that Caesar sees an apparition, though Patria's words rather than her actual form are most important here. Walde also notes that Patria's mourning is a sign to Caesar that he will be victorious. This could well be true, but one must also recognize that such a sign would be welcome only to someone who had come to have little regard for the wishes of his own country. 
describes unjust acts being justified and traditional notions of $i u s$ and civis being inverted. ${ }^{44}$ However, between the statement of the theme in the opening lines and the later examples of it, Caesar is warned at the Rubicon that he may still avoid transgression. Thus the river represents a final chance for him to respect what is right. Structurally, the Rubicon marks the point in the poem where the right or wrong conduct of citizens ceases to be an assertion of the narrator and begins to be reflected in the characters' own actions.

Lucan's Caesar crosses the river, of course, but not without trepidation and then self-justification. Significantly, Caesar is afraid not at the sight of his Patria but at her challenge to his conduct, and this fear stops him at the very edge of the river, on the verge of transgressing his duty (1.192-194). But as he gathers himself and responds forcefully, he also appeals to authorities that are higher than the law. He calls upon the traditional gods of his family and his state to recognize that he, not his opponents, is fighting on their behalf, and that therefore it is his enemies who are harming the state and doing wrong (1.195-203). At the end of the speech, he responds directly to Patria's command to respect the boundary (buc usque licet) by asking for her endorsement to carry on the war:

"en, adsum victor terraque marique

Caesar, ubique tuus (liceat modo, nunc quoque) miles.

ille erit ille nocens, qui me tibi fecerit hostem."

"Behold, here I am, victor on land and sea,

Caesar, everywhere your soldier; may I only be allowed to be your soldier

now, as well.

He will be the guilty one-that man who will have made me your enemy."

Caesar's self-justification captures the contradictory nature of his request: he could be named both tuus miles and tibi hostis. His desire to cross the Rubicon puts great weight on terms such as ius and civis. Matthew Roller argues that Caesar is attempting to "assimilate" himself to Patria in response to her-and his enemies'-attempt to "alienate" him by branding his actions inappropriate for a citizen. ${ }^{45}$ This conflict over his status reflects the rhetoric of factions in a civil war, and parallels the problems of loyalty that appear in the Phoenissae and are discussed by Cicero. Lucan is not alluding directly to Euripides or to Cicero, but in treading the same thematic ground he encounters the same problems. Thus his Caesar wrestles against a familiar notion of patriotic duty as he attempts

\footnotetext{
${ }^{44}$ On the inverted notion of citizenship, cf. Laelius' claim: nec civis meus est, in quem tua classica, Caesar, / audiero (1.373-374); for Martindale (1984: 69), Laelius' depravity confirms that Caesar's actions are criminal. On ius overturned by Caesar's tyranny, cf. Figulus' prediction: imminet armorum rabies, ferrique potestas / confundet ius omne manu, scelerique nefando / nomen erit virtus, multosque exibit in annos / bic furor. et superos quid prodest poscere finem? / cum domino pax ista venit (1.666-670).

${ }^{45}$ Roller 2001: 38.
} 
to justify his decision to make war on Rome, and he echoes the words both of Eteocles, who would not relinquish power, and of Polyneices, who attacked his own country in order to recover it. In one exchange between Jocasta and her sons, Polyneices asserts that he is being excluded from Thebes unjustly, but Eteocles responds that even so, by attacking the city, he has become an enemy to his patria ( $\pi \alpha \tau \rho i ́ \delta o \varsigma . . \pi \mathrm{o} \lambda \varepsilon \dot{\mu} \mu 1 \mathrm{\varsigma}, 609$ ); and even Polyneices must admit to his mother that because of his decision to wage war, he is no longer her son (619). Lucan's Caesar acknowledges the same problem as he responds to Patria, but he will vow a few lines later to overcome this problem by force of arms. ${ }^{46}$

As the narrative progresses, however, Caesar's argument does not convince Patria, a fact marked not by Patria herself, who remains silent after her rebuke, but by the Rubicon. When Caesar first approaches its banks, the river is small (ut ventum est parvi Rubiconis ad undas, 1.185). Immediately after his plea, without waiting for Patria to respond, he drives through the "swollen river" (inde moras soluit belli tumidumque per amnem / signa tulit propere, 1.204-205). The Rubicon has become a more serious obstacle during the course of the intervening dialogue, and the breadth of the river reflects Patria's assertion that it stands for the boundary between respect for and transgression of what is right. Lucan's Caesar, however, is energized by his defiance of Patria and by his domination of the river. He crosses just as a lion stalks the fields of Libya, angry and majestic, and pressing on despite wounds inflicted by hunter-enemies (1.205-212). Lucan even returns to the difficulty of the crossing, and thus further emphasizes its significance, in a second description of the river, where he explains how the Rubicon is reduced by the heat of summer, but during winter, the season of Caesar's approach, it is swollen by rain (1.213-219). Then, as if the reader might not have perceived exactly what Caesar has done, Lucan describes the crossing for a second time, all in terms of domination: first the cavalry stood across the current to check its flow (excepturus aquas); then the soldiers easily crossed the broken river (molli tum cetera rumpit / turba vado facilis iam fracti fluminis undas); and finally Caesar himself crossed (or conquered?) the stream (superato gurgite) and "stood on the forbidden fields of Hesperia" (Hesperiae vetitis et constitit arvis, 1.220-224). Lucan closes the scene by having Caesar, now in Italy, speak again to declare his contrary view of who exactly is in the wrong:
"bic" ait "bic pacem temerataque iura relinquo;
te, Fortuna, sequor. procul hinc iam foedera sunto;
credidimus satis his, utendum est iudice bello."
"Here," he says, "here I abandon peace and defiled rights; you, Fortune, I follow. Let agreements now be far away from me;

\footnotetext{
${ }^{46}$ Narducci (2002: 199-200) vividly describes what lies at the heart of the problem: he compares Caesar's arrival at the Rubicon to accounts of other Roman and Greek generals who led their armies across significant boundaries, pointing out that Caesar, "con un radicale mutamento di direzione" (200), has turned his forces toward his homeland instead of taking them further afield.
} 
I have trusted enough in these-now war must be the judge."

Caesar's bic, repeated for emphasis, echoes the huc of Patria, but Caesar reverses the significance of "this place." Despite Patria's insistence, the Rubicon no longer represents respect for an old-fashioned ius that subordinates the citizen to the state. Instead, the river marks the point where Fortuna supersedes Patria, and where a citizen may begin to justify his actions through victory in war. ${ }^{47}$

We do not have to look hard to find an intersection between Lucan's confrontation at the Rubicon and his earlier commentary on Caesar's character and career. Lucan prefaces Caesar's arrival at the river by describing a general moral decline at Rome that is similar to the one described by Sallust in his Bellum Catilinae (especially the Archaeology and 53.2-5). This decline in turn has especially corrupted those who hold high office (1.158-182). Thus Patria is already weary when she confronts Caesar's imminent invasion and his disregard for good republican citizenship. She requests that he act according to ius, an ideal that should have guaranteed the proper conduct of a citizen toward his state, and the swollen river serves to indicate that Lucan's Patria, like Cicero, does not accept Caesar's self-justification. ${ }^{48}$ Patria does not speak again, but if Lucan had given her a response, she might well have made a protest similar to Cicero's rejection of Caesar's excuses in the Second Philippic: there could be no justification for taking up arms against one's own country. ${ }^{49}$ Even having Patria appear to denounce a citizen who is charged with attacking the state is a trick from Cicero's rhetorical playbook. Several literary antecedents have been suggested for Lucan's apparition, but whatever the inspiration, her appearance in Lucan's poem feels like a reprisal of her role in the First Catilinarian (17-19). ${ }^{50}$

The outlook of Lucan's Patria, however, is quite different from that of Cicero. His Patria knew, as Cicero did not, that Caesar's commencement of civil war effectively marked the end of the respublica. Thus his Patria makes a brief protest and then, when refuted, withdraws before Caesar's advance, unlike Cicero's Patria, whose moral weight helped to precipitate Catiline's flight from Rome, and unlike Cicero himself, who nursed his anger at Caesar's "tyrannical" actions even after the Ides of March, eventually redirecting his patriotic arguments toward Antony. Nonetheless, Lucan's Patria brings the same idea of republican citizenship to bear in her protest at the Rubicon, demonstrating exactly what is

${ }^{47}$ I will return to the role of Fortuna below, 93.

${ }^{48}$ There is no need to suggest that the republican authors were sources for Lucan, however, since all the authors were dealing with familiar ethical and rhetorical ideas. Pichon (1912) established the still prevalent view that Lucan depended mainly on Livy; see Lintott 1971: 488, n. 6, for a summary of the scholarship on Lucan's sources. Malcovati (1953: 293) argues against a direct influence of Att. 7.11 on Lucan but sees other signs of Cicero's letters in the poem; see also Holliday 1969.

${ }^{49}$ See above, 78, n. 9.

${ }^{50}$ On suggested models for Lucan's Patria, including the First Catilinarian, see Masters 1992: 1, n. 4; on uses of patria in similar rhetorical situations, see Narducci 2002: 196-197. 
at stake in the crossing and what is lost when she withdraws. That is to say, she is acknowledging the reality of what Cicero feared: when consensus about ius has been lost, the individual citizen is free to redefine the res publica for himself. ${ }^{51}$

\section{FORTUNE AND THE LOSS OF THE REPUBLIC}

All three imperial authors, in fact, have an advantage over Cicero, because they already know the future as they write about the Rubicon and the outbreak of war. The republic will pass away, but that process in itself will not mark the end of the Roman state. Even so, each author deals uniquely with the loss of the republic as symbolized by the crossing. This is especially evident with regard to fortune, which is a beneficial force in Suetonius, in contrast to the ambivalent role that it plays in Plutarch, as we have seen, and its negative role in Lucan. Among the three, Lucan is unique in that Caesar does not call upon fortune until after he has crossed the Rubicon. ${ }^{52}$ His purpose as he recovers from his initial fear and confronts the apparition appears certain; it is only once he is across that Lucan speaks again of hesitation. There, just as the Euripidean Eteocles claimed Tyrannis as his patron (against his mother's pleas for Isotes), so Caesar chooses Fortuna over Patria. But in Lucan, as in Suetonius, Fortuna is not neutral. Working with fate, she actively aids Caesar in his bid to overturn ius:

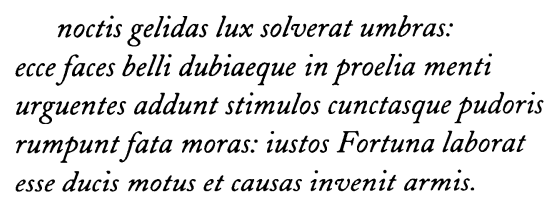

The light dissolved the cold shadows of night; behold! the fates are supplying the torches of war; to his mind hesitating over battle, they give the pressing spur; and they destroy

\footnotetext{
${ }^{51}$ Cf. Bartsch (1997: 14), who writes that Lucan's poem is set in motion by the crossing of the Rubicon, "an act that transgresses both law and nation." Lucan himself, however, even as his Patria acknowledges Caesar's assault on republican government, is not necessarily taking a personal stand, at least at this point in the poem. The Rubicon scene follows closely on the proem to the Bellum Civile, the tone of which is debated but which nonetheless proclaims that the evils of civil war (scelera ipsa nefasque) were a fair price to pay for Nero's ascent (1.33-66). Later in the poem, Lucan will openly lament the political changes brought about by the civil war, charging that freedom was driven from the empire by those same evils (fugiens civile nefas ... / Libertas... recessit, 7.427-436) and castigating Fortuna for providing a dominus for his generation but no means of resistance (7.645-646). Some argue that the more hostile attitude of the later books reflects the deterioration of Lucan's own political standing, which in turn affected his views of Nero and the principate; see Ahl 1976: 42-44; Fantham 1992: 13-14; and the critical discussion of Roller (2001: 17-20). In the Rubicon scene, however, Patria and her most ambitious citizen are debating a citizen's obligation to his state.

${ }^{52}$ Cf. Dick 1967: 238.
} 
every shame-inspired delay. Fortune works to make the actions of the general just, and she finds reasons for war.

For both Lucan and Suetonius, then, the appeal to fortune is answered immediately and affirms what Caesar wishes. But there is an important difference as well. Suetonius sees the crossing as prompted, even forced, by a divine sign, and is evidently accepting of the event. Lucan, on the other hand, has Caesar cross the Rubicon by his own decision. Then, once he has dismissed Patria and crossed the river, the fates and Fortuna work to strengthen his resolve and to justify his actions. Lucan's Caesar, therefore, possesses more self-determination than Suetonius', who watches as the phantom leads the charge, and also more than Plutarch's, who crosses the river with an impulse of spirit but without resolving his doubt. In Lucan, Fortuna's late endorsement of Caesar's decision to cross the Rubicon makes the gods look weak, as if they too have been subdued by Caesar's aggressiveness, and thus Lucan's reader is not obliged to accept either Caesar's decision or, by extension, the ensuing loss of the republic. ${ }^{53}$

Their implied views about the loss of the republic also differentiate the three narratives. The view presented by Lucan's poem in general has been the object of much scholarly discussion and is certainly beyond the scope of this article. But in support of the fundamental difference between the narratives of Lucan and Suetonius, we may look to this statement by Frederick Ahl:

Lucan's new Rome begins, not with the first of the principes, but with the first of the Caesars, as Suetonius' Lives do. And this new Rome is much worse than the old. Not only does it rise from the ashes of the old; its founder, Julius Caesar, brought the old Rome to ruin. ${ }^{54}$

Lucan's Rubicon narrative, with its dramatic rejection of Patria, represents Caesar's first step in bringing the old Rome to ruin. Suetonius, in contrast, does not ask his reader to dwell on the loss of the republic. His immediate literary predecessors publicly eulogized the princeps (e.g., Plin. Paneg.) and, following the

\footnotetext{
${ }^{53}$ Lucan, in fact, may be condemning Caesar's decision when he adds the endorsement of Fortuna. See Fantham (1992: 10), who writes, "Nothing within De bello civili accepts the gods (or Fortuna) as benevolent or just"; cf. Brisset 1964: 88. Davies (2004: 116-123) explains the role of Fortuna in Livy's history and, as part of his discussion, writes that "Fortuna is unequivocally linked to the dispensations of the gods" (121). This appears also to be the assumption of Lucan and Suetonius, though, as Fantham noted, Lucan does not assume that the gods have Rome's best interests in mind, while Suetonius implies that the gods' endorsement makes the action right. There would also have been a religious aspect to the crossing of the Rubicon, as with the crossing of any river, though this is not stressed by any of the authors. See Holland (1961: 16-17), who notes Suetonius' passing remark that horses had been consecrated at the Rubicon (81.2). She believes that the Greek authors (Plutarch and Appian) were unaware of a possible ritual significance to Caesar's pausing at the river, and attributes the silence in the Roman texts ("even in Lucan") about any religious rites performed at the Rubicon to the fact that the practice of taking auspices had fallen into obscurity by the time the Roman authors composed their narratives.

${ }^{54}$ Ahl 1976: $57-58$.
} 
bad years of Domitian, found relief in Nerva's blending of monarchy and liberty (principatus, libertas) and in Trajan's efforts to promote prosperity (felicitas; Tac. Agr. 3). ${ }^{55}$ While not necessarily praising the principate, Suetonius shows no inclination to criticize it either. Indeed, if we compare the assassination scene from his life of Domitian with the similar passage from that of Caesar, we find ourselves in very familiar territory:

Per baec terribilis cunctis et invisus, tandem oppressus est insidiis amicorum libertorumque intimorum simul et uxoris. ${ }^{56}$

Having made himself frightful and hated by all through these actions, he was at last killed by a conspiracy of his friends and closest freedmen, with the cooperation of his wife (Dom. 14.1).

"These actions" are Domitian's arrogant words and deeds, described in the preceding chapters. However, the vices that stirred hatred against Domitian in particular do not undermine the emperor in general. Thus the last Caesar in Suetonius' series dies for precisely the same reason as the first: for his abuse of power while ruling, not simply for being a monarch.

Plutarch, as we have seen, occupies an even less political position. In his Caesar, the Rubicon becomes a philosophical problem, the site of a moral dilemma that makes a point about excessive ambition, not about good republican citizenship. A contemporary of Lucan (though writing his Caesar after Lucan's death), he refrains from commenting on the destruction of the republic even at the critical moment of the crossing. ${ }^{57}$ But he was not always so detached. He wrote his Caesares, a work that must have touched on a multitude of unjust and violent episodes in the development of the imperial system. We read in the Otho, for instance, how Plutarch himself visited the battlefield between Bedriacum and Cremona, the scene of the decisive encounter between the forces of Otho and Vitellius, and how his friend Mestrius Florus pointed out to him the place where the Roman dead had been heaped up (14.2). ${ }^{58} \mathrm{He}$ did not as a rule shy away from the empire's bloody and unjust past; ${ }^{59}$ but neither was he dominated by

${ }^{55}$ The bibliography on the attitudes of Pliny and Tacitus toward the principate is large, but see Morford 1991 and 1992; see also Sailor 2004: 150, n. 33, for further bibliography. For the younger Pliny's influence on the political career of Suetonius, see Bradley 1991: 3704-09.

${ }^{56}$ This sentence has several variants in the Mss; I am following Rolfe's Loeb edition since Ihm's Teubner does not decide among them.

${ }^{57}$ According to Jones (1966), the Parallel Lives were probably composed between the years 96 and 120, and relative dating makes it likely that the Caesar was composed after 99.

${ }^{58}$ In connection with this battle, Plutarch, like Tacitus (Hist. 2.44), notes that the slaughter of troops is especially great in civil wars, since prisoners have no value. Cf. Otho 18.2, where Plutarch reports that he saw Otho's tomb at Brixellum. See further Syme 1980: 105 and Bowersock 1998.

${ }^{59} \mathrm{Cf}$. Ant. 19.4, where Plutarch reports the deals made by Antony, Octavian, and Lepidus to spare some and kill others of their fellow citizens, adding that "nothing, in my opinion, was more savage or uncivilized than this exchange" and that the three were "more unjust" to their friends than to their enemies. 
it. Like Lucan, he came of age during the reign of Nero, but like Suetonius, he also lived well beyond both the turbulent year 69 and the reign of Domitian. As a learned Greek who was well aware of his own nation's bloody past, he understood the political and social benefits of the imperial system. When he settled into writing about Caesar, he seems to have been far enough removed from the self-destruction of the Julio-Claudians that he could contemplate the Rubicon rationally. For Plutarch as for Suetonius, the republic had naturally given way to the principate, his own political and intellectual world..$^{60}$

Although the data points are few, by way of conclusion I would like to suggest a trend in writing and thinking about the Rubicon. Cicero, although he did not discuss the Rubicon per se, serves as a useful comparandum when we read the imperial narratives. His ideological argument against Caesar's civil war must have carried some weight in his own time; otherwise he would not have revived it after the Ides or expected it to be rhetorically effective in the $D e$ officiis or the Second Pbilippic. ${ }^{61}$ For Lucan, an argument made on essentially the same basis as Cicero's was still useful, even if it merely represented an old-fashioned perspective on the republic that had been forcefully rebutted and then set aside several generations earlier. By the early second century, however, the recollection of republican ideals at this moment of crisis seems to have lost its appeal, so that Plutarch could narrate the crossing of the Rubicon with philosophical detachment and Suetonius did not feel compelled to question its propriety, even as he turned to Cicero himself for source material. If a distressed Patria could still confront Caesar with a republican notion of citizenship during the reign of Nero, she appears to have become quite comfortable with the reality of the principate by the time of Hadrian. ${ }^{62}$

\section{Department of Classics \\ UNIVERSITY OF WiSCONSIN \\ 1220 Linden Drive \\ Madison, WI 53706 \\ U.S.A.}

jbeneker@wisc.edu

\footnotetext{
${ }^{60}$ See further Dillon 1997 and Pelling 2002b: 262.

${ }^{61}$ It is worth noting that other contemporary writers held more favorable views of Caesar, even after his death. Diodorus Siculus eulogizes Caesar and says that he was called a god "because of what he had done" (32.27.3); on his admiration for Caesar, see Sacks 1990: 172-184. Nicolaus of Damascus characterizes the grievances of most of Caesar's assassins as jealousy or anger cloaked in concern for the republic ( $F G r H F$ 130.60), and he can be defensive of Caesar's autocratic power (e.g., F 70).

${ }^{62}$ Earlier versions of this article were presented at the universities of Wisconsin and Iowa, and at the 2007 meeting of the Classical Association of the Middle West and South in Cincinnati. I am very grateful for the helpful discussion that occurred on each occasion. I owe special thanks to Bradley Buszard, Timothy Duff, Craig Gibson, Carin Green, Marc Kleijwegt, Laura McClure, and the anonymous referees of Phoenix, whose comments and criticism at various stages in this article's development have greatly improved the final version.
} 
BIBLIOGRAPHY

Ahl, F. 1976. Lucan: An Introduction. Ithaca.

Bartsch, S. 1997. Ideology in Cold Blood: A Reading of Lucan's Civil War. Cambridge, MA.

Beneker, J. 2002/2003. "No Time for Love: Plutarch's Chaste Caesar," GRBS 43: 13-29.

Bonner, S. F. 1949. Roman Declamation in the Late Republic and Early Empire. Liverpool.

Bowersock, G. W. 1998. "Vita Caesarum: Remembering and Forgetting the Past," in S. M. Maul and W.-W. Ehlers (eds.), La biographie antique: huit exposés suivis de discussions. Genève. 193-215.

Bradley, K. R. 1991. "The Imperial Ideal in Suetonius' 'Caesares', $A N R W$ II.33.5: 3701-3732.

Brisset, J. 1964. Les idées politiques de Lucain. Paris.

Brunt, P. A. 1986. "Cicero's Officium in the Civil War," JRS 76: 12-32.

Buszard, B. 2008. "Caesar's Ambition: A Combined Reading of Plutarch's AlexanderCaesar and Pyrrhus-Marius," TAPA 138: 185-215.

Butler, H. E., M. Cary, and G. B. Townend. 1982. Suetonius: Divus Julius. Bristol.

Cizek, E. 1977. Structures et idéologie dans "Les vies des douze Césars" de Suétone. Bucharest and Paris.

Clarke, M. L. 1968. "Cicero at School," GESR s.s. 15: 18-22.

Cribiore, R. 2001. "The Grammarian's Choice: The Popularity of Euripides' Phoenissae in Hellenistic and Roman Education," in Y. L. Too (ed.), Education in Greek and Roman Antiquity. Leiden and Boston. 241-259.

Davies, J. P. 2004. Rome's Religious History: Livy, Tacitus and Ammianus on their Gods. Cambridge.

Dick, B. F. 1967. "Fatum and Fortuna in Lucan's Bellum Civile," CP 62: 235-242.

Dillon, J. 1997. "Plutarch and the End of History," in J. M. Mossman (ed.), Plutarch and his Intellectual World. London. 235-240.

Dubourdieu, H. 1951. "Le Passage du Rubicon d'après Suétone, César et Lucain," L'Information littéraire 3: 122-126, 162-165.

Duff, T. E. 1999. Plutarch's Lives: Exploring Virtue and Vice. Oxford.

Dyck, A. R. 1996. A Commentary on Cicero, De Officiis. Ann Arbor.

Dyer, R. R. 1990. "Rhetoric and Intention in Cicero's Pro Marcello," JRS 80: 17-30.

Fantham, E. 1992. Lucan: De bello civili, Book II. Cambridge.

Frank, T. 1907. "Caesar at the Rubicon," CQ 1: 223-225.

Gelzer, M. 1968. Caesar: Politician and Statesman. Tr. P. Needham. Cambridge, MA.

1969. Cicero: ein biographischer Versuch. Wiesbaden.

Gotoff, H. C. 1993. Cicero's Caesarian Speeches: A Stylistic Commentary. Chapel Hill.

Hohl, E. 1952. "Cäsar am Rubico," Hermes 80: 246-249.

Holland, L. A. 1961. Janus and the Bridge. Rome.

Holliday, V. L. 1969. Pompey in Cicero's Correspondence and Lucan's Civil War. The Hague.

Jal, P. 1963. La guerre civile à Rome: étude littéraire et morale. Paris.

Jones, C. P. 1966. "Towards a Chronology of Plutarch's Works," JRS 56: 61-74. Reprinted in Scardigli 1995: 95-123.

Kohl, R. 1915. De scholasticarum declamationum argumentis ex historia petitis. Paderborn. 
Lintott, A. W. 1971. "Lucan and the History of the Civil War," CQ n.s. 21: 488-505.

- 2008. Cicero as Evidence: A Historian's Companion. Oxford.

Long, A. A. 1995. "Cicero's Politics in De officiis," in A. Laks and M. Schofield (eds.), Justice and Generosity: Studies in Hellenistic Social and Political Philosophy. Proceedings of the Sixth Symposium Hellenisticum, Cambridge. 213-240.

Malcovati, E. 1953. "Lucano e Cicerone," Athenaeum 31: 288-297.

Martindale, C. 1984. "The Politician Lucan," GESR s.s. 31: 64-79.

Masters, J. 1992. Poetry and Civil War in Lucan's Bellum Civile. Cambridge.

Morford, M. 1991. "How Tacitus defined Liberty," $A N R W$ II.33.5: 3420-3450.

— 1992. "Iubes Esse Liberos: Pliny's Panegyricus and Liberty," AJP 113: 575-593.

Morgan, L. 2000. "The Autopsy of C. Asinius Pollio," JRS 90: 51-69.

Narducci, E. 2002. Lucano: un'epica contro l'impero. Roma.

Pelling, C. 1979. "Plutarch's Method of Work in the Roman Lives," JHS 99: 74-96. Reprinted with new postscript in Scardigli 1995: 265-318, and with revisions in Pelling 2002a: 1-44.

- 1997. "Tragical Dreamer: Some Dreams in the Roman Historians," GESR 44: 197-213.

- 2002a. Plutarch and History. Swansea and London.

— 2002b. "Plutarch's Caesar: A Caesar for the Caesars?," in Pelling 2002a: 253-265.

- 2004. "Plutarch on the Outbreak of the Roman Civil War," in H. Heftner and

K. Tomaschitz (eds.), Ad Fontes! Festschrift für Gerbard Dobesch zum fünfundsechzigsten Geburtstag am 15. September 2004: dargebracht von Kollegen, Schülern und Freunden. Vienna. 317-327.

2006a. "Breaking the Bounds: Writing about Caesar," in J. M. Mossman and

B. C. McGing (eds.), The Limits of Ancient Biography, Swansea: 255-280.

2006b. "Judging Julius Caesar," in Wyke 2006: 3-26.

Pichon, R. 1912. Les sources de Lucain. Paris.

Raaflaub, K. A. 1974. Dignitatis contentio: Studien zur Motivation und politischen Taktik im Bürgerkrieg zwischen Caesar und Pompeius. München.

Ramsey, J. T. 2003. Cicero: Philippics I-II. Cambridge.

- 2007. Sallust's Bellum Catilinae ${ }^{2}$. Oxford and New York.

Rawson, E. 1970. "Family and Fatherland in Euripides' Phoenissae," GRBS 11: 109-127. 1975. Cicero: A Portrait. London.

Renehan, R. 1969. Greek Textual Criticism: A Reader. Cambridge, MA.

Roller, M. B. 2001. Constructing Autocracy: Aristocrats and Emperors in Julio-Claudian Rome. Princeton.

Rondholz, A. 2009. "Crossing the Rubicon: A Historiographical Study," Mnemosyne 62: 432-450.

Sacks, K. S. 1990. Diodorus Siculus and the First Century. Princeton.

Sailor, D. 2004. "Becoming Tacitus: Significance and Inconsequentiality in the Prologue of Agricola," Cl. Ant. 23: 139-177.

Scardigli, B. ed. 1995. Essays on Plutarch's Lives. Oxford.

Shackleton Bailey, D. R. 1968. Cicero: Letters to Atticus. Volume IV, 49 B.C., 133-210 (Books VII.10-X). Cambridge.

1971. Cicero. New York.

Stockton, D. L. 1971. Cicero: A Political Biography. Oxford. 
Swain, S. 1989. "Plutarch: Chance, Providence, and History," AJP 110: 272-302.

Syme, R. 1980. "Biographers of the Caesars," Museum Helveticum 37: 104-128.

Tucker, R. A. 1988. "What Actually Happened at the Rubicon?," Historia 37: 245-248.

Walde, C. 2006. "Caesar, Lucan's Bellum Civile, and Their Reception," in Wyke 2006: 45-61.

Wallace-Hadrill, A. 1983. Suetonius: The Scholar and His Caesars. London.

Weinstock, S. 1971. Divus Julius. Oxford.

Winterbottom, M. 1994. M. Tulli Ciceronis de officiis. Oxford.

Wiseman, T. P. 1996. "Crossing the Rubicon, and Other Dramas," SCI 15: 152-158.

Wood, N. 1988. Cicero's Social and Political Thought. Berkeley.

Wyke, M. ed. 2006. Julius Caesar in Western Culture. Oxford.

Yavetz, Z. 1971. "Caesar, Caesarism, and the Historians," Journal of Contemporary History 6: $184-201$. 